\title{
Barriers for children with mental problems in accessing child psychiatry services in Japan
}

\author{
Keiichi Funahashi ${ }^{1}$, Takeo Fujiwara ${ }^{2 *}$ and Makiko Okuyama ${ }^{3}$ \\ *Correspondence: fujiwara-tk@ncchd.go.jp CrossMark \\ 'Department of Psychiatry, Saitama Children's Medical Center, Saitama, Japan. \\ 2Department of Social Medicine, National Research Institute for Child Health and Development, Tokyo, Japan. \\ ${ }^{3}$ Department of Psychosocial Medicine, National Center for Child Health and Development, Tokyo, Japan.
}

\begin{abstract}
There are a substantial number of children with mental problems who do not visit medical institutions due to various reasons. The purpose of our research is to describe the barriers for such children in accessing hospitals which provide child psychiatric services. For the study, we recruited caregivers whose children first visited one of the 16 leading hospitals where child psychiatric service are provided, between September 2008 to March 2009 ( $n=4,323$; average age: 13 years old). In terms of difficulty in finding services, 67.2\% of the caregivers responded with "difficult" or "very difficult". It took an average of 2.4 years to visit a hospital after the first recognition of the signs of mental problems. Before visiting a children's psychiatric hospital, $86.3 \%$ had consulted other services such as general pediatricians (26.0\%), educational institute (12.7\%), and public health centers (18.7\%); while only $13.7 \%$ of the respondents visited a hospital specializing in child psychiatric services right from the beginning. In terms of awareness of the availability of appropriate services and hospitals, $41.4 \%$ of the caregivers had prior knowledge while $22.9 \%$ obtained information from the internet; suggesting that online information is useful in offering guidance and support. The most common symptoms which attracted caregivers' attention include behavioral problems (21\%), delay in development (18\%), and problems interacting with other people (16\%). We propose that an effective healthcare system for child mental problems be developed through the establishment of a network system comprising of medical, public health, welfare, and educational agencies.
\end{abstract}

Keywords: Children, mental health, developmental disabilities, cooperation

\section{Introduction}

Due to the increasing prevalence in child mental problems and abuse, there is an urgent need to develop a network system for such children [11]. In a Japanese survey of approximately 10,000 randomly sampled nursery schools, elementary and junior high schools, the percentage of children with mental problems that were severe enough to render a visit to a medical institution were $4.6 \%, 2.9 \%$, and $4.2 \%$, respectively [7]. However, only a small percentage of these children actually visited a hospital which provides child psychiatric services; $15.9 \%$ in nursery school, $12.3 \%$ in elementary school, and $12.3 \%$ in junior high school. Further, some of the caregivers of the children did not know where they should be going for consultation.

In Western societies, there was a debate on the necessity of training sufficient child psychiatrists and the establishment of a network to handle the largely unmet needs of children with mental problems [5]. There was also a discussion on whether pediatricians or psychiatrists should be treating such children, or if their roles should be shared [10]. It was pointed out that general pediatricians, who usually serve as gatekeepers in childhood diseases, should be adequately trained in identifying mental problems and making referrals to psychiatrists when necessary [3]. In a recent pilot project in Massachusetts, USA, instead of pediatricians who usually have time constraints, behavioral outreach workers cooperated with schools and child counseling centers to enhance referral of children with mental problems to child psychiatrists or appropriate social welfare services, producing positive results [4].

In view of these studies, it is necessary to first investigate the current situation, that is, how caregivers of children with mental problems encounter difficulties in accessing hospitals with child psychiatric services, before a medical network system to address children with mental problems in Japan be developed. Also, it is crucial to study how mental problems in children are recognized by caregivers, as well as what process they go through before visiting a specialized hospital, and how much time it takes from the first recognition of symptoms to the first visit to a hospitals which provide child psychiatric services. Here, we investigated these factors.

\section{Methods}

\section{Participants}

Caregivers of children with mental problems who visited 16 leading hospitals in Japan that specialize in child psychiatric service were recruited for this study. A questionnaire was disseminated to all the new patients who visited the hospitals 
Funahashi et al. Paediatrics and Health 2014,

between September 2008 to March 2009, as well as to those who were already in treatment in September 2008. We requested the child psychiatrists who were in charge of the examination and treatment of the patients to pass on the questionnaire to the patients in order to enhance response rate. Respondents to the questionnaire were allowed to remain anonymous; however, the hospitals were identified by colorcoding of the question papers. All questionnaires were returned to the National Center for Child Health and Development. In total, 11,577 doctors received the questionnaires which resulted in 4,323 responses (response rate: $34 \%$ ).

\section{Measures}

The respondents to the questionnaire were caregivers of the children with mental problem. In the questionnaire, the demographic characteristics of the patients were queried, including first recognition of symptoms by caregivers, the type of symptoms as chief complaints, age at first recognition of symptoms, and the type of institution they first consulted. Further, the difficulty in finding an appropriate institution for consultation upon first recognition of the mental problem was assessed by a 5-Likert scale: extremely difficult, slightly difficult, undecided, not very difficult, not difficult at all. The factors investigated included: why respondents first consulted an institution other than a hospital that specializes in the child psychiatric services but subsequently visited a specialized hospital, who recommended a visit to a child psychiatric hospital, who recommended a visit to a specialized hospital even though they were not referred at the previously consulted institution, and by which way did the caregivers find out about the specialized hospitals. In addition, the duration from the first recognition of symptoms to the first visit of a specialized hospital was queried.

\section{Ethics committee approval}

Our study was approved by the Ethics Committee (institutional review board) of the National Center for Child Health and Development.

\section{Results}

The demographic characteristics of the children with mental problems are shown in (Table 1 ). About two-thirds were males $(66.8 \%)$. Their average age of the children was 13.0 years old. $38.3 \%$ were elementary school students and $26.7 \%$ were junior high school students, accounting for nearly two thirds of the participants in the study. $74.9 \%$ of the participants have mental or developmental problems but have not taken advantage of special education or schools for students with other disabilities. Most of the participants (96.2\%) were living at home. $84.9 \%$ of the respondents were the biological mother.

The chief complaints are shown in (Table 2). There was a very wide range of symptoms; the most common were behavioral problems (21.2\%), delay in development (18.4\%), problems interacting with other people (16.5\%), and non-attendance
Table 1. Characteristics of participants (children with mental problems, $n=4,323)$.

\begin{tabular}{|c|c|c|c|}
\hline & & Mean or $\mathbf{N}$ & $\begin{array}{l}\text { SD or } \\
\text { percentage }\end{array}$ \\
\hline Age & -- & 13.0 & 5.5 \\
\hline \multirow[t]{2}{*}{ Gender } & Male & 2,864 & 66.8 \\
\hline & Female & 1,422 & 33.2 \\
\hline \multirow{5}{*}{$\begin{array}{l}\text { Main place of } \\
\text { residence }\end{array}$} & Home & 4,144 & 96.2 \\
\hline & Foster home & 7 & 0.2 \\
\hline & $\begin{array}{l}\text { Facility for disabled } \\
\text { children }\end{array}$ & 25 & 0.6 \\
\hline & $\begin{array}{l}\text { Other child welfare } \\
\text { facilities }\end{array}$ & 65 & 1.5 \\
\hline & Other & 69 & 1.6 \\
\hline \multirow{8}{*}{$\begin{array}{l}\text { Institution in } \\
\text { which the child } \\
\text { was enrolled }\end{array}$} & Nursery school & 190 & 4.4 \\
\hline & Kindergarten & 163 & 3.8 \\
\hline & Elementary school & 1,640 & 38.3 \\
\hline & Junior high school & 1,144 & 26.7 \\
\hline & High school & 573 & 13.4 \\
\hline & Specialized school & 21 & 0.5 \\
\hline & University & 49 & 1.1 \\
\hline & Other & 501 & 11.7 \\
\hline \multirow[t]{4}{*}{ System used } & $\begin{array}{l}\text { Facilities for disabled } \\
\text { children attending } \\
\text { nursery school, etc. }\end{array}$ & 137 & 3.3 \\
\hline & Special education system & 539 & 13.0 \\
\hline & $\begin{array}{l}\text { Schools for the other } \\
\text { disabled }\end{array}$ & 369 & 8.9 \\
\hline & No system used & 3,113 & 74.9 \\
\hline \multirow[t]{11}{*}{ Respondent } & Biological mother & 3,832 & 89.4 \\
\hline & Biological father & 290 & 6.8 \\
\hline & Stepmother & 10 & 0.2 \\
\hline & Stepfather & 3 & 0.1 \\
\hline & Grandmother & 42 & 1.0 \\
\hline & Grandfather & 9 & 0.2 \\
\hline & Foster mother & 7 & 0.2 \\
\hline & Foster father & 0 & 0.0 \\
\hline & $\begin{array}{l}\text { Employee in charge at } \\
\text { the facility }\end{array}$ & 70 & 1.6 \\
\hline & Director of the facility & 1 & 0.0 \\
\hline & Other & 23 & 0.5 \\
\hline
\end{tabular}

at school (11.7\%). The average age at which the symptoms were noticed was 7.1 years old (standard deviation $=4.6$ years). The level of difficulty faced by caregivers of children with mental problems in knowing which institution they should be going for consultation are shown in (Table 3). $40.5 \%$ of the respondents reported that they found it 'extremely difficult', 
Funahashi al. Paediatrics and Health 2014,

Table 2. First recognized symptoms - chief complaints $(n=4,323)$.

\begin{tabular}{|c|c|c|c|}
\hline & Major symptoms & $\mathbf{N}$ & $\%$ \\
\hline \multirow[t]{21}{*}{ Major complaint } & Delay in development & 742 & 18.4 \\
\hline & $\begin{array}{l}\text { Problems while interacting with other } \\
\text { people }\end{array}$ & 665 & 16.5 \\
\hline & Obsessiveness & 208 & 5.2 \\
\hline & Behavioral problems & 854 & 21.2 \\
\hline & $\begin{array}{l}\text { Non-attendance at school } \\
\text { (kindergarten, etc.) }\end{array}$ & 474 & 11.7 \\
\hline & $\begin{array}{l}\text { Physical symptoms thought to be } \\
\text { caused by mental problems }\end{array}$ & 156 & 3.9 \\
\hline & Problems with toilet training & 22 & 0.5 \\
\hline & Problems with eating behavior & 94 & 2.3 \\
\hline & Autism & 37 & 0.9 \\
\hline & Habitual problems & 83 & 2.1 \\
\hline & Excessive anxiety & 68 & 1.7 \\
\hline & Depression & 120 & 3.0 \\
\hline & Problems related to delinquency & 21 & 0.5 \\
\hline & Suicidal and self-injurious behavior & 105 & 2.6 \\
\hline & Sleeping problems & 26 & 0.6 \\
\hline & Problems related to abuse & 31 & 0.8 \\
\hline & Problems related to trauma & 80 & 2.0 \\
\hline & $\begin{array}{l}\text { Hallucinations (auditory } \\
\text { hallucinations, visual } \\
\text { hallucinations, etc.) }\end{array}$ & 37 & 0.9 \\
\hline & Delusions & 13 & 0.3 \\
\hline & Drug dependency & 0 & 0.0 \\
\hline & Other & 202 & 5.0 \\
\hline
\end{tabular}

Table 3. Difficulty in finding an appropriate institution for consultation upon first recognition of symptoms $(n=4,323)$.

\begin{tabular}{lll}
\hline & N & Percentage \\
\hline Extremely difficult & 1,735 & 40.5 \\
Slightly difficult & 1,146 & 26.7 \\
Undecided & 295 & 6.9 \\
Not very difficult & 749 & 17.5 \\
Not difficult at all & 298 & 7.0 \\
Do not know & 62 & 1.5 \\
\hline
\end{tabular}

while $26.7 \%$ felt that it was 'slightly difficult'.

The type of institution which the respondents first consulted upon recognition of symptoms in their children are shown in (Table 4). The results reveal that the main starting points were pediatric clinics and pediatric departments in hospitals; general pediatricians (26.0\%), educational institute (12.7\%), and public health centers (18.7\%). $13.7 \%$ of the respondents visited a hospital specializing in child psychiatric services from the beginning.
Table 4. First consulted institution $(n=4,323)$.

\begin{tabular}{|c|c|c|c|}
\hline & & $\mathbf{N}$ & Percentage \\
\hline $\begin{array}{l}\text { Hospitals specializing in child } \\
\text { mental problems }\end{array}$ & & 585 & 13.7 \\
\hline \multirow{7}{*}{$\begin{array}{l}\text { Other hospitals } \\
\text { Medical institutions }\end{array}$} & & 3,696 & 86.3 \\
\hline & -- & 1,475 & 41.5 \\
\hline & Pediatric clinics & 423 & 11.9 \\
\hline & $\begin{array}{l}\text { Pediatric } \\
\text { departments in } \\
\text { hospitals }\end{array}$ & 501 & 14.1 \\
\hline & $\begin{array}{l}\text { Psychiatric } \\
\text { clinics }\end{array}$ & 270 & 7.6 \\
\hline & $\begin{array}{l}\text { Psychiatric } \\
\text { departments in } \\
\text { hospitals }\end{array}$ & 169 & 4.8 \\
\hline & $\begin{array}{l}\text { Internal } \\
\text { medicine } \\
\text { clinics }\end{array}$ & 112 & 3.2 \\
\hline $\begin{array}{l}\text { Educational } \\
\text { guidance centers and } \\
\text { education centers }\end{array}$ & & 450 & 12.7 \\
\hline $\begin{array}{l}\text { Child counseling } \\
\text { centers }\end{array}$ & & 311 & 8.8 \\
\hline $\begin{array}{l}\text { Health centers and } \\
\text { public health centers }\end{array}$ & & 663 & 18.7 \\
\hline $\begin{array}{l}\text { Home child } \\
\text { counseling centers, } \\
\text { welfare offices }\end{array}$ & & 144 & 4.1 \\
\hline Child home centers & & 39 & 1.1 \\
\hline $\begin{array}{l}\text { Psychological } \\
\text { consultation with the } \\
\text { police }\end{array}$ & & 6 & 0.2 \\
\hline Other & & 466 & 13.1 \\
\hline
\end{tabular}

The number of respondents who first consulted an institution other than a hospital specialized in child psychiatric services, but subsequently visited a specialized hospital, was 3,696. Of those, 1,781 were referred from the previously consulted institution (49.9\%). $12 \%$ of the respondents changed hospitals as they were not satisfied with the consulted institutions $(n=430,12.1 \%)$. The main reason for the change was to seek a second opinion (315 respondents, $8.8 \%$ ), while the rest cited other reasons (1,040 respondents, $29.2 \%)$.

(Table 5$)$ shows the type of individuals $(n=585)$ who recommended a visit to a specialized hospital from the beginning. In $34.9 \%$ of the cases, the caregivers were the ones who made the judgment, while $2.4 \%$ of the cases were recommended by another family member living with the child, and $4.8 \%$ were recommended by a relative not living with the child. In $28.7 \%$ of the cases, the schoolteacher was the one making the recommendation. Recommendation through public health or welfare centers accounted for only $6.5 \%$ of the cases.

(Table 6) shows who recommended a visit to a specialized 
Funahashi et al. Paediatrics and Health 2014,

http://www.hoajonline.com/journals/pdf/2052-935X-2-3.pdf

Table 5. Main types of individuals who recommended an initial visit to a specialized hospital $(n=585)$.

\begin{tabular}{lll}
\hline & N & Percentage \\
\hline Parents & 204 & 34.9 \\
Schoolteacher & 168 & 28.7 \\
$\begin{array}{l}\text { Health center, family and child } \\
\text { counseling center, or child family center }\end{array}$ & 27 & 4.6 \\
Child guidance center & 11 & 1.9 \\
Other family member living with the child & 14 & 2.4 \\
Other relative not living with the child & 28 & 4.8 \\
Acquaintance & 52 & 8.9 \\
Communication through the Internet & 4 & 0.7 \\
Other & 102 & 17.4 \\
\hline
\end{tabular}

hospital even though the patients were not referred to the specialized hospital at the previously consulted institution, which include general pediatrics or educational institutions ( $n=1785)$. In $42.7 \%$ of the cases, the parents made the judgment, while $16.9 \%$ were recommended by a schoolteacher. Recommendations by an acquaintance or a previous medical institution accounted for $17.1 \%$ and $16.5 \%$ of the cases, respectively.

The ways by which the caregivers knew about a specialized hospital without a referral or recommendation $(n=966)$ are shown in (Table 7). $41.4 \%$ of them already had prior knowledge, while $22.9 \%$ of them found out through the internet.

The distribution of the time period from the first recognition of the symptoms to the first visit to a specialized hospital in child psychiatric services is shown in (Figure 1). The mean period was 2.4 years (standard deviation, 2.8 years; range, 1 day to 35 years). In $22 \%$ of cases, the time period was four years or more.

Table 6. Main types of individuals who recommended specialized hospitals without referral $(n=1,785)$.

\begin{tabular}{|c|c|c|}
\hline & $\mathbf{N}$ & Percentage \\
\hline Parents & 762 & 42.7 \\
\hline $\begin{array}{l}\text { Previously consulted medical institution } \\
\text { (including other medical departments in the same } \\
\text { hospital) }\end{array}$ & 295 & 16.5 \\
\hline Schoolteacher & 301 & 16.9 \\
\hline $\begin{array}{l}\text { Health center, family and child counseling center, } \\
\text { or child family center }\end{array}$ & 133 & 7.5 \\
\hline Child guidance center & 67 & 3.8 \\
\hline Other family member living with the child & 26 & 1.5 \\
\hline $\begin{array}{l}\text { Grandparent or other relative not living with the } \\
\text { child }\end{array}$ & 70 & 3.9 \\
\hline Acquaintance & 306 & 17.1 \\
\hline Communication on the Internet & 26 & 1.5 \\
\hline Other & 325 & 18.2 \\
\hline
\end{tabular}

Table 7. Ways by which caregivers were made aware of specialized hospitals $(n=966)$.

\begin{tabular}{lll}
\hline & N & Percentage \\
\hline Prior knowledge & 400 & 41.4 \\
$\begin{array}{l}\text { Previously consulted medical } \\
\text { institution }\end{array}$ & 88 & 9.1 \\
$\begin{array}{ll}\text { Through a person who had visited the specialized } \\
\text { hospital }\end{array}$ & 111 & 11.5 \\
Internet & 221 & 22.9 \\
Parents' association & 55 & 5.7 \\
Schoolteacher & 71 & 7.3 \\
Public health center, health center, welfare office & 69 & 7.1 \\
Child counseling center & 36 & 3.7 \\
Through a relative or an acquaintance & 56 & 5.8 \\
Other & 211 & 21.8 \\
\hline
\end{tabular}

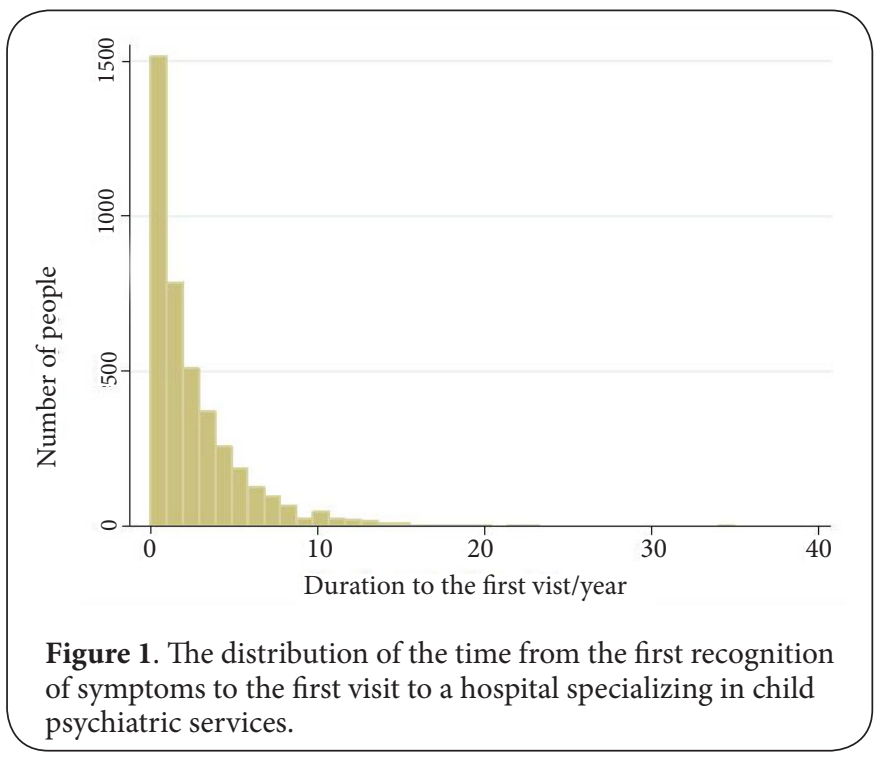

\section{Discussion}

We have demonstrated that a majority of caregivers of children with mental problems experienced difficulty in knowing where they should go for consultation. Based on our findings, we believe that many of the caregivers, despite noticing symptoms on mental or behavioral problems in their children, did not have a proper channel or suitable person for them to seek advise from. As such, they had to make their own judgment and decision when it comes to getting their children to the right institution [1].

Surveyed youths, together with their caregivers, who had visited an emergency department with mental problems, on what they had expected in terms of assistance. The study found that caregivers would like to have support guidance for their child, assessment, evaluation or diagnosis of the problems, and health care professional resources; the lack of knowledge of mental health services and referral procedures among caregivers 
Funahashi al. Paediatrics and Health 2014,

of children with mental problems was evidently highlighted. While mental problems in children do not render the kind of urgency usually required by acute diseases, there is still a possibility that a delay in seeking appropriate treatment after symptoms first appeared could cause worsening of the condition, which in turn leads to onerous, long-term treatment [6]. Furthermore, it is no doubt beneficial to minimize the period of anxiety experienced by the child and the family members caused by uncertainties prior to a proper consultation.

For this reason, it is therefore necessary for institutions that handle a wide range of children's problems to identify the symptoms promptly and to refer them appropriately. Alternatively, for multiple institutions to fulfill that role, each institution should have an equal capacity in its role in providing guidance as well as identifying and referring cases of mental problems. As we have shown that the first point of consultation was pediatric clinics or pediatric departments in hospitals, a larger role is therefore expected of these entities with regards to identifying mental problems in children.

The American Academy of Pediatrics proposed that primary care pediatricians should address mental health and substance abuse problems and recommended the steps to achieve that goal [2]; including promoting healthy lifestyles, preventing and mitigating mental health and substance abuse problems, and improve accessibility to mental healthcare services. We propose similar approaches and goals should be set for Japan as well [6].

Reported that when they used a school-based health centers approach, the proportion of students accessing mental healthcare services increased; further, the students had significantly lower total healthcare and mental healthcare services cost. While there is no similar mental healthcare system in Japan, educational institutions can serve as good starting-point for consultation, and make referrals accordingly. As such, we suggest that the cooperation between educational institutions and hospitals specializing in pediatric mental health be further strengthened, From the results, we can deduce that the internet is effective in answering to the demands of caregivers in terms of guidance and support. In a survey by [12] of 3,746 people aged $12-25$ years and 2,005 co-resident parents, $71 \%$ of the respondents rated websites and books as likely to be helpful as sources of information about mental health. Similarly, [9] demonstrated that mental health information on websites was strongly preferred due to the ability of users to remain anonymous.

We found that the average period of time from the first recognition by caregivers of the symptoms in their children to the first visit to the specialized hospital for child psychiatric services was 2.4 years; a significant time period for children. As a substantial percentage of participants took the initiative to visit a specialized hospital, we hypothesize that there is a potential deficiency within the network of related institutions for getting referrals in Japan. In Finland, a set of nationwide standardized criteria (the Finnish Child Psychiatric Criteria
Tool) for assessing the need for specialized child psychiatric medical care was made publicly accessible on the internet [8]. The sensitivity and specificity of the tool was $82 \%$ and $74 \%$, respectively; it was concluded that the tool was able to ascertain the need for specialized child psychiatric medical care. Moreover, the criteria development process prompted multisectional discussion on the organization of child mental health services and the need for a defined health policy for such conditions. We believe that similar criteria can be applied in Japan as well. Above all, there is a critical need for the related institutions to have a discussion on standardizing the criteria.

Emotional resistance of the caregiver or children towards visiting a specialized hospital for child psychiatric services could be another factor in explaining the period of 2.4 years. However, we are aware that selection bias may have resulted in the long duration; we included severe cases which required a visit specialized hospital, while patients whose symptoms improve during the natural course of their condition were not included in this study. Further community-based study is warranted to examine the duration from the recognition of the symptoms to the fist visit to the specialized hospital.

In view of the wide range of symptoms observed by caregivers, it is necessary to develop a strategy to form a network of general pediatrics, educational institutions, public health and welfare centers, and specialized hospital on child mental problems by each symptoms, to enhance efficient referral.

\section{Conclusion}

We found that the majority of the caregivers of children with mental problems severe enough to visit a specialized hospital experienced difficulties in seeking appropriate help upon first recognition of symptoms. As such, the strengthening of a network system comprising of general pediatrics, educational institutions, public health and welfare system and specialized hospitals is needed to promote early detection and treatment of the children with mental problems.

\section{Competing interests}

The authors declare that they have no competing interests.

Authors' contributions

\begin{tabular}{|l|c|c|c|}
\hline Authors' contributions & KF & TF & MO \\
\hline Research concept and design & $\checkmark$ & $\checkmark$ & $\checkmark$ \\
\hline Collection and/or assembly of data & $\checkmark$ & -- & $\checkmark$ \\
\hline Data analysis and interpretation & -- & $\checkmark$ & -- \\
\hline Writing the article & $\checkmark$ & $\checkmark$ & -- \\
\hline Critical revision of the article & $\checkmark$ & $\checkmark$ & $\checkmark$ \\
\hline Final approval of article & $\checkmark$ & $\checkmark$ & $\checkmark$ \\
\hline Statistical analysis & -- & $\checkmark$ & -- \\
\hline
\end{tabular}

\section{Acknowledgement}

This research is supported by Research on Healthcare System for Children with Mental Problems and Development of Child 
Funahashi et al. Paediatrics and Health 2014,

http://www.hoajonline.com/journals/pdf/2052-935X-2-3.pdf

Psychiatrist, in Research on Children and Families, Health and Labor Sciences Research Grants from Ministry of Health, Labor, and Welfare (PI: Makiko Okuyama). We would like to thank Dr. Julian Tang of the Department of Education for Clinical Research, National Center for Child Health and Development, for proofreading and editing this manuscript.

\section{Publication history}

EIC: Victor C. Strasburger, UNM School of Medicine, USA.

Received: 18-Feb-2014 Final Revised: 13-Mar-2014

Accepted: 14-Mar-2014 Published: 05-Apr-2014

\section{References}

1. Cloutier P, Kennedy A, Maysenhoelder H, Glennie EJ, Cappelli M and Gray C. Pediatric mental health concerns in the emergency department: caregiver and youth perceptions and expectations. Pediatr Emerg Care. 2010; 26:99-106. | Article | PubMed

2. Policy statement--The future of pediatrics: mental health competencies for pediatric primary care. Pediatrics. 2009; 124:410-21. | Article | PubMed

3. Dulcan MK, Costello EJ, Costello AJ, Edelbrock C, Brent D and Janiszewski $\mathrm{S}$. The pediatrician as gatekeeper to mental health care for children: do parents' concerns open the gate? J Am Acad Child Adolesc Psychiatry. 1990; 29:453-8. | Article | PubMed

4. Fujiwara $\mathrm{T}$ and Chan MH. Role of behavioral outreach worker in increasing mental health service utilization for children. Pediatr Int. 2009; 51:167-8. | Article | PubMed

5. Grant NR, Offord DR and Blum HM. Ontario Child Health Study. Implications for clinical services, research and training. Can J Psychiatry. 1989; 34:492-9. I PubMed

6. Guo JJ, Wade TJ and Keller KN. Impact of school-based health centers on students with mental health problems. Public Health Rep. 2008; 123:768-80. | PubMed Abstract | PubMed Full Text

7. Izumi M and Okuyama M. A survey of children with mental health problems in Japanese nursery, elementary and journior high school. The Journal of the Japan Pediatric Society. 2008; 112:476-482.

8. Kaukonen P, Salmelin RK, Luoma I, Puura K, Rutanen M, Pukuri T and Tamminen T. Child psychiatry in the Finnish health care reform: national criteria for treatment access. Health Policy. 2010; 96:20-7. | Article | PubMed

9. Leach LS, Christensen H, Griffiths KM, Jorm AF and Mackinnon AJ. Websites as a mode of delivering mental health information: perceptions from the Australian public. Soc Psychiatry Psychiatr Epidemiol. 2007; 42:167-72. | Article | PubMed

10. Menahem $S$. The contribution of the paediatrician and psychiatrist to the management of the child, adolescent and his family--a paediatrician's viewpoint. Aust Paediatr J. 1987; 23:235-9. | Article | PubMed

11. Ministry of Health Labor and Welfare. Report on training of child psychiatry specialists. Tokyo 2007.

12. Oh E, Jorm AF and Wright A. Perceived helpfulness of websites for mental health information: a national survey of young Australians. Soc Psychiatry Psychiatr Epidemiol. 2009; 44:293-9. | Article | PubMed

\section{Citation}

Funahashi K, Fujiwara T and Okuyama M. Barriers for children with mental problems in accessing child psychiatry services in Japan. Paediatr Health. 2014; 2:3. http://dx.doi.org/10.7243/2052-935X-2-3 